\title{
Native aortic coarctation stenting in adults and adolescents: early and mid-term results of an adult interventional cardiology team
}

Zabiegi stentowania natywnej koarktacji aorty u dorosłych i nastolatków - wczesne i średnioterminowe wyniki leczenia prowadzonego przez zespół interwencyjnego leczenia kardiologicznego dorosłych

\author{
Ramazan Akdemir ${ }^{1}$, Huseyin Gunduz', Sani Murat ${ }^{2}$, Harun Kilic ${ }^{3}$, Ekrem Yeter ${ }^{3}$, Mustafa Tarik Agaç, \\ Zeydin Acar', Yuksel Kaya ${ }^{5}$, Mehmet Dogan ${ }^{4}$, Mehmet Bulent Vatan' ${ }^{1}$, Mehmet Akif Cakar ${ }^{1}$, Ali Fuat Erdem
}

1Department of Cardiology, Faculty of Medicine, Sakarya University, Sakarya, Turkey

2Department of Cardiology, Research and Education Hospital, Etlik Ihtisas, Ankara, Turkey

${ }^{3}$ Department of Cardiology, Diskapi Yildirim Beyazit Research and Education Hospital, Ankara, Turkey

4Department of Cardiology, Ahi Evren Heart and Vascular Surgery Training and Research Hospital, Trabzon, Turkey

5Department of Cardiology, Van Yüksek Ihtisas Hospital, Van, Turkey

Post Kardiol Interw 2012; 8, 1 (27): 8-13

DOI: $10.5114 / p w k i .2012 .27919$

\begin{abstract}
Background: Stent implantation has evolved as an important therapeutic strategy for aortic coarctation.

Aim: This study aimed to present the experience of aortic coarctation stenting using the Cheatham-Platinum stent by an Adult Interventional Cardiology Team.

Material and methods: The data of 11 patients (ages were between 15 to 58 years) who underwent aortic coarctation stent implantation between 2008 and 2011 for moderate to severe native aortic coarctation were retrospectively collected.

Results: Average systolic blood pressure was $175 \pm 35 \mathrm{~mm} \mathrm{Hg}$, and mean diastolic blood pressure was $115 \pm 15 \mathrm{~mm} \mathrm{Hg}$. Pressure gradient proximal and distal to aortic coarctation was $55.5 \pm 17.7$ before the stenting. The invasive gradient decreased below $10 \mathrm{~mm} \mathrm{Hg}$ in all patients. There were no complications except in one patient whose subclavian artery was occluded without any clinical finding. One patient had a totally occluded lesion, needing perforation for acquired interruption using a 0.35 inch hydrophilic wire under the supporting balloon. There was no aneurysm or restenosis at follow-up. Left ventricular functions completely recovered within 1 month in all patients.

Conclusions: Stenting using the Cheatham-Platinum stent, either covered or bare, is safe in moderate to severe native aortic coarctation and provides an excellent transcoarctation gradient and clinical hypertension and left ventricular functional relief in adult patients.
\end{abstract}

Key words: aortic coarctation, angioplasty, Cheatham-Platinum stent

\section{Streszczenie}

Wstęp: Implantacja stentu stała się ważną metodą leczenia koarktacji aorty.

Cel: Celem badania było przedstawienie doświadczenia zespołu interwencyjnego leczenia kardiologicznego dorosłych w stentowaniu koarktacji aorty z użyciem stentu Cheatham-Platinum.

Materiał i metody: Dokonano retrospektywnej analizy danych 11 pacjentów (w wieku 11-58 lat), u których wykonano implantację stentu w miejsce koarktacji aorty. Zabiegi przeprowadzono pomiędzy 2008 a 2011 rokiem u pacjentów z natywną koarktacją aorty w stopniu od umiarkowanego do ciężkiego.

Wyniki: Średnia wartość skurczowego ciśnienia tętniczego wynosiła $175 \pm 35$ mm Hg, a średnie ciśnienie rozkurczowe $115 \pm 15 \mathrm{~mm}$ Hg. Przed zabiegiem wszczepienia stentu gradient ciśnienia pomiędzy miejscem proksymalnie i dystalnie do koarktacji aorty wynosit $55,5 \pm 17,7$ mm Hg. U wszystkich pacjentów osiągnięto spadek gradientu w pomiarze inwazyjnym do wartości poniżej $10 \mathrm{~mm} \mathrm{Hg}$. $\mathrm{U}$ jednego pacjenta doszło do zamknięcia tętnicy podobojczykowej bez innych klinicznych następstw. Poza tym nie wystąpiły inne 
powikłania. U jednego pacjenta doszło do całkowitej niedrożności, co wymagało sforsowania miejsca okluzji (nabytego przerwania ciągłości aorty). W tym celu użyto hydrofilnego prowadnika o średnicy 0.35 cala z wykorzystaniem balonu w celu uzyskania podparcia. W trakcie obserwacji nie wytworzył się tętniak i nie wystąpiła restenoza. Funkcja lewej komory całkowicie się poprawiła u wszystkich pacjentów w ciągu miesiąca po zabiegu.

Wnioski: Zabieg stentowania z użyciem stentów Cheatham-Platinum (stentgraftów lub zwykłych stentów) jest bezpieczny w przypadku natywnej koarktacji aorty w stopniu umiarkowanym do ciężkiego oraz prowadzi u dorosłych pacjentów i wiąże się z bardzo dobrymi wynikami w postaci zniesienia gradientu przez koarktację, ustąpienia nadciśnienia systemowego i poprawy funkcji lewej komory.

Słowa kluczowe: koarktacja aorty, angioplastyka, stent Cheatham-Platinum

\section{Background}

Aortic coarctation ( $\mathrm{COA})$ is a common congenital heart disease, which may be isolated or present as part of other congenital cardiac abnormalities [1]. The CoA is found in $5-8 \%$ of all congenital cardiac defects, and the majority of cases are detected and treated during childhood [1]. However, some cases may present with hypertension or congestive heart failure in adults. Half of the patients with CoA die during the first decade of life and only $10 \%$ survive into the fifth decade [1]. Surgical therapy is associated with a very low risk of restenosis and recurrence, whereas endovascular therapy has a much higher incidence of restenosis and the need for repeat interventions [2]. Transcatheter treatments for CoA include balloon angioplasty and stent implantation. Previous studies have shown that balloon angioplasty (BAP) and stenting have similar procedural success and early and late complications in $\operatorname{CoA}[3,4]$. The immediate improvement in hypertension and morbidity were similar across all groups [5-12].

\section{Aim}

The aim of this retrospective study is to present the experience of our adult cardiology team with stenting of CoA using the Cheatham-Platinum (CP) stent in an adult and adolescents patient population.

\section{Material and methods}

Data on CoA cases treated with stenting between 2008 and 2011 were collected retrospectively. The study was approved by the Sakarya University Faculty of Medicine Ethics Committee, and informed consent was obtained from all patients. Diagnosis of CoA was based on a combination of clinical signs (arm-leg blood pressure (BP) difference > $20 \mathrm{~mm} \mathrm{Hg}$ ); non-invasive imaging including echocardiography, computerized tomography (CT) scan, or magnetic resonance imaging (MRI); and/or invasive gradient measurements. Patients who had ventricular septal defect, atrial septal defect, or any other congenital abnormalities except bicuspid aorta were excluded from the study. Eleven patients with isolated CoA underwent stenting at five cardiology centers. A non-covered stent was chosen for the first two patients in 2008 and 2009. Two of the patients served as online learning cases for the National
Interventional Cardiology Congress created by the authors. One of them had complete aortic occlusion due to coarctation and underwent stenting using a covered CP stent (NuMED CP stent, Heart Medical Europe BV, Best, Netherlands) in 2009, and the second live teaching case was in 2010 .

\section{Preprocedural imaging}

All patients underwent transthoracic echocardiography (Vivid-3, GE Healthcare, Israel) and 64-slice CT angiography to define their anatomy and any associated cardiac or vascular abnormalities. Repeat echocardiographic examinations were performed $24 \mathrm{~h}$ after the procedure and at follow-up to evaluate stent position and the presence of any residual gradients. The $\mathrm{CT}$ angiography was performed in 3 patients immediately after completion of the procedure due to severe back pain and showed normally opened stents in all cases.

\section{Procedure}

Informed written consent was obtained from all patients. All procedures were performed under deep sedation with anesthetic support. Patients were heparinized with 5,000 IU with activated clotting time (ACT) monitoring after the sheaths were placed. Only a femoral sheath was placed for cardiac catheterization in patients with less than total occlusion. Catheterization was performed in all patients to determine the exact morphology and pressure gradient. Aortography was performed in the lateral, antero-posterior, and left anterior oblique positions. In 8 patients, the CoA segment was traversed with a 0.035 -inch diameter hydrophilic guide wire. In 1 patient, the wire could not be passed from the distal aorta to the proximal part due to total occlusion and a second brachial artery sheath was placed to guide passing into the true proximal aortic lumen.

Coronary hydrophilic and total occlusion wires were first tried in both brachial and femoral artery approaches but were ineffective. A 0.32-inch j-tipped hydrophilic guide wire was used to support the introduction of a JR4 diagnostic catheter via the femoral artery. The diagnostic JR catheter was placed distal to the occlusion. Using proximal contrast injections, a small branch vessel was cannulated and the hydrophilic guide wire was passed across the 
occlusion into the proximal part of the aorta to terminate in the small vessel. We then forced the diagnostic catheter over the guide wire to reach the proximal aorta. At this stage 10,000 units of intra-arterial heparin were given. We then replaced the wire with a 0.014 -inch coronary guide wire, removed the diagnostic catheter, and a $4 \times 20-\mathrm{mm}$ coronary balloon (Cordis ${ }^{\circledR}$ - a Johnson\&Johnson Company, USA) was inflated three times. Next, a $14 \times 20-\mathrm{mm}$ balloon angioplasty (BAP) balloon (Cordis ${ }^{\circledR}-$ a Johnson\&Johnson Company, USA) was inflated three times gradually using low 6-8 atm of pressure and then completely with 14 atm. Luminal blood flow was achieved, but a small dissection occurred in the occluded region. The pressure gradient dropped to $35 \mathrm{~mm} \mathrm{Hg}$. After angioplasty, the femoral sheath was exchanged with a 14-F sheath, and a 0.032inch hydrophilic guide wire was placed into the left subclavian artery. A $22 \times 40-\mathrm{mm}$ covered stent (Numed Inst, NY, USA) was loaded over a BIB balloon (Numed Inst, NY, USA). Successful implantation was performed by consecutive balloon inflation using nominal pressures. The pressure gradient dropped to $5 \mathrm{~mm} \mathrm{Hg}$, and final angiography showed excellent results [5].

\section{Stent procedure}

Measurements of ascending aorta, transverse arch, isthmus, CoA site, proximal and distal to the obstruction, and at the level of the diaphragm were performed by quantitative angiography to determine the exact stent size. After determining the stent size, the 6-F sheath was removed and a 14-F long sheath (William Cook Europe, Bjaeverskov, Denmark) was placed into the femoral artery through the coarctation segment. A covered or bare CP stent was loaded over a balloon-in-balloon (BIB) (NuMED Inc, Heart Medical Europe BV, Best, The Netherlands) catheter. An Amplatz super stiff guide wire was placed into the right or left subclavian artery or left ventricle. A temporary pacemaker lead was also placed at the apex of the right ventricle.

The balloon-mounted stent was advanced to the proper position across the coarctation site under angiographic guidance using the brachial sheath. An inner balloon to fix the stent in the coarctation site followed by an outer balloon were inflated while the right ventricle was paced at 180 beats per minute using the temporary pacing wire. When the stent was expanded properly, temporary pacing was stopped, and balloons were deflated and removed from the long sheath. Baseline angiography using a pigtail was done to evaluate stent positioning, deployment, and any other complication or vessel occlusion.

The procedure was terminated if the stent was in an acceptable position and size, and the pressure gradient adequately decreased. Procedural success was established when the invasive gradient was less than $10 \mathrm{~mm} \mathrm{Hg}$. Acetylsalicylic acid, $100 \mathrm{mg} /$ day, was administered for 6 months in all patients.

\section{Clinical data}

All patients were evaluated by echocardiography and data such as blood pressure and heart rate were recorded on the next day, at 1 and 6 months, and yearly thereafter. Assessment of BP in all extremities, antihypertensive medication needs, chest X-ray, echocardiography, and CT angiography were evaluated every 6 months. Hypertension was defined as blood pressure (BP) values $\geq 140 \mathrm{~mm} \mathrm{Hg}$ systolic or $\geq 90 \mathrm{~mm} \mathrm{Hg}$ diastolic, according to the JNC VI guidelines.

\section{Statistical analysis}

The SPSS statistical program for Windows, version 15 (SPSS Inc., Chicago, Illinois, USA) was used to perform data analysis. Non-normally distributed continuous data are presented as median (interquartile range) and mean \pm SD (ranges). Categorical variables were compared using the $\chi^{2}$ test. All statistical tests were two-sided. A $p$ value $<0.05$ was considered statistically significant.

\section{Results}

The clinical and demographic data of the 11 patients are shown in Table 1. Fluoroscopic time was $20 \pm 15 \mathrm{~min}$ (range: $15-50 \mathrm{~min}$ ) and procedure time was $30 \pm 15 \mathrm{~min}$ (range: 25-45 min). Nine patients had native CoA. Stenting was successfully performed in all patients. Covered stents were implanted in nine patients and non-covered CP stents were used in 2. In 1 patient, the guide wire could not be passed across the coarctation, and brachial artery puncture was performed. In the remaining 10 patients, the lesion was passed easily and a stent was deployed under rapid right ventricular pacing. Predilatation was performed in 2 patients, 1 of whom had total occlusion, and the second had severe stenosis. Predilations were performed gradually using $14 \times 20-\mathrm{mm}$ Tyshak balloons (NuMED, Hallenweg-Netherlands) (Figure 2). The proximal aortic pressure was $176.6 \pm 22.9 \mathrm{~mm} \mathrm{Hg}$ before the procedure. Pressure gradients were significantly decreased from $55.5 \pm 17.7 \mathrm{~mm} \mathrm{Hg}$ before, to $6.5 \pm 1.6 \mathrm{~mm}$ $\mathrm{Hg}$ by invasive measures $(p=0.0001)$.

\section{Complications}

The 14-F long sheaths were used in all patients. There were no groin hematomas or hemorrhage necessitating blood transfusion. There were no procedure-related deaths, stent maldeployment, or stent embolization. None of the patients required intensive care admission following the procedure, and they were all discharged home the following day except the patient with total aortic occlusion who had a hypotensive course for $6 \mathrm{~h}$ after the procedure. In 1 patient, the left subclavian artery was occluded by a covered stent during the procedure without any sequelae. There was no left arm pain or steal symptoms. We considered a second procedure after consulting the cardiovascular surgical team, but because the patient remained asymptomatic on follow-up visits, there was no indication for a second procedure. 
Table 1. Patient characteristics and procedure results

Tabela 1. Charakterystyka pacjentów i wyniki zabiegów

\begin{tabular}{|c|c|c|c|c|c|c|c|c|c|}
\hline Patient no. & $\begin{array}{c}\text { Age } \\
\text { [years] }\end{array}$ & Gender & $\begin{array}{l}\text { Blood } \\
\text { press }\end{array}$ & Gradient & $\begin{array}{l}\text { Stent } \\
\text { type }\end{array}$ & $\begin{array}{l}\text { Stent length } \\
{[\mathrm{mm}]}\end{array}$ & $\begin{array}{l}\text { Diameter } \\
{[\mathrm{mm}]}\end{array}$ & $\begin{array}{l}\text { Final } \\
\text { gradient }\end{array}$ & LVEF \\
\hline 1 & 55 & $M$ & $180 / 110$ & 50 & CP bare MS & 32 & 24 & 5 & 20 \\
\hline 2 & 22 & $M$ & $150 / 100$ & 40 & CP bare MS & 28 & 22 & 8 & 50 \\
\hline 3 & 23 & $M$ & $200 / 120$ & 100 & CP covered & 48 & 24 & 6 & 45 \\
\hline 4 & 24 & $\mathrm{~F}$ & $170 / 100$ & 55 & CP covered & 42 & 22 & 9 & 55 \\
\hline 5 & 19 & $M$ & $160 / 100$ & 60 & CP covered & 32 & 22 & 8 & 55 \\
\hline 6 & 25 & $\mathrm{~F}$ & $220 / 130$ & 50 & CP covered & 42 & 24 & 5 & 55 \\
\hline 7 & 15 & $M$ & $150 / 100$ & 45 & CP covered & 28 & 20 & 5 & 60 \\
\hline 8 & 24 & $\mathrm{~F}$ & $180 / 110$ & 45 & CP covered & 32 & 22 & 8 & 60 \\
\hline 9 & 19 & $M$ & $180 / 120$ & 55 & CP covered & 42 & 24 & 5 & 55 \\
\hline 10 & 16 & $M$ & $160 / 100$ & 45 & CP covered & 34 & 18 & 8 & 60 \\
\hline 11 & 17 & $F$ & $200 / 110$ & 48 & CP covered & 34 & 18 & 5 & 60 \\
\hline
\end{tabular}

\section{Follow-up}

All patients were followed up with average duration of $15.2 \pm 6.9$ months (median: 12 months; range: 1-29 months). All patients underwent a $\mathrm{CT}$ angiographic evaluation at 6 months.

\section{Discussion}

This study presents the experience with CoA stenting in an adult patient population from our country. All procedures were successful and there were no deaths or sig-

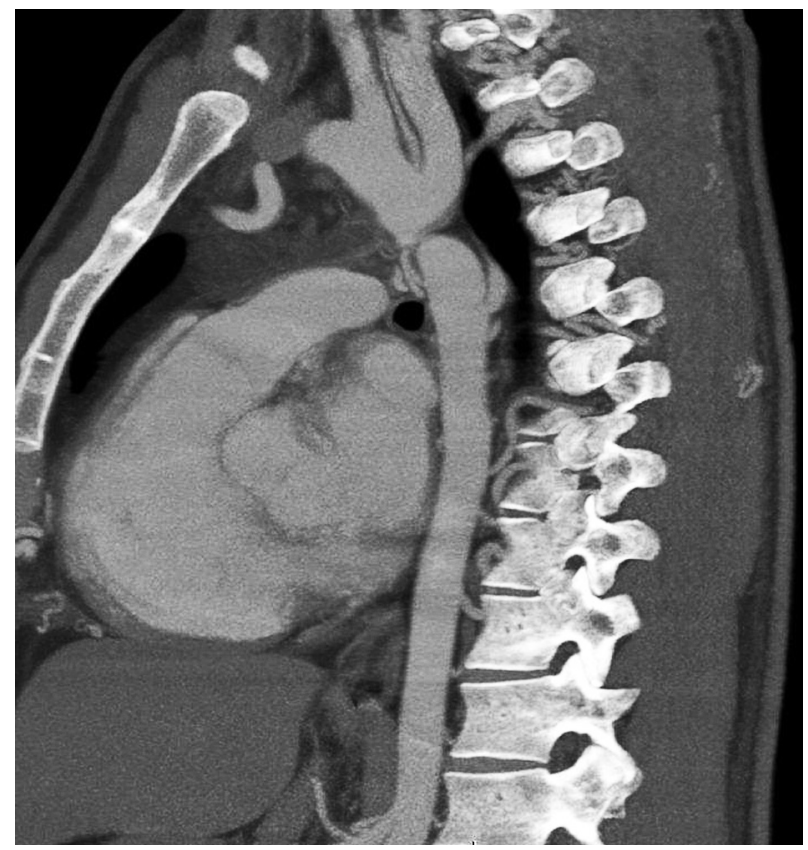

Fig. 1. Multislice CT angiography shows severe aortic coarctation

Ryc. 1. Angiografia metoda wielowarstwowej tomografii komputerowej - widoczna ciężka koarktacja aorty nificant complications except 1 patient whose left subclavian artery was occluded by a covered stent. Due to absence of left arm pain or steal symptoms, the patient did not require a second procedure. Only limited centers and operators perform CoA stenting in our country and the majority of them are pediatric cardiologists. This is the second largest series of COA stenting in adults in our coun-

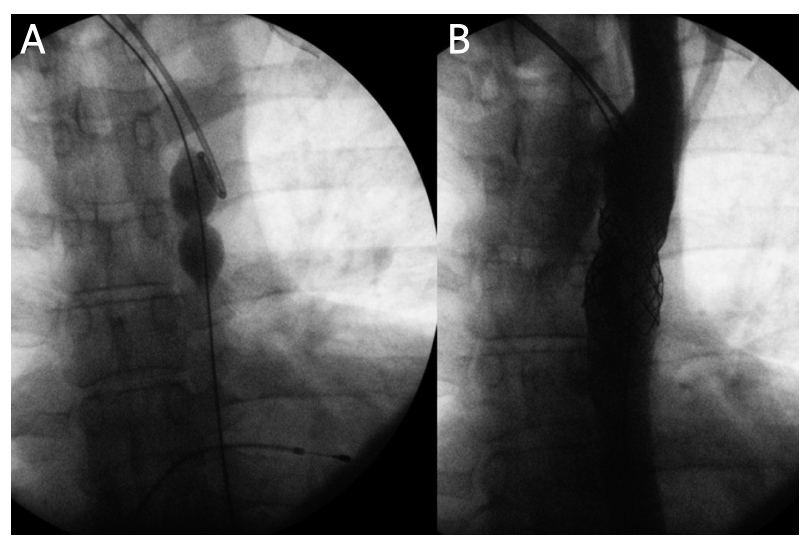

Fig. 2 A-B. Angioplasty and covered stent implantation

Ryc. 2 A-B. Angioplastyka i implantacja stentgraftu

Table 2. Summary of procedural variables

Table 2. Podsumowanie danych dotyczacych parametrów przed zabiegiem i po zabiegu

\begin{tabular}{lccc} 
Variables & Before stenting & After stenting & Value of $p$ \\
\hline Invasive grad. & $55.5 \pm 17.7$ & $6.5 \pm 1.6$ & 0.0001 \\
\hline LVEF & $50.5 \pm 12.3$ & $55.2 \pm 4.7$ & 0.004 \\
\hline Systolic BP & $176.6 \pm 22.9$ & $136.2 \pm 14.3$ & 0.001 \\
\hline Diastolic BP & $111.1 \pm 11.667$ & $80.5 \pm 9.8$ & 0.002 \\
\hline Echo grad. at 6 months & $15.4 \pm 4.3$ &
\end{tabular}


try [12-14]. Our patient group consisted of adult patients different from the studies of Erdem and Baykan, both of which presented experiences with CoA stenting in pediatric patients. The technique for CoA stenting we used in this group has some different features. First, we routinely used rapid right ventricular temporary pacing during balloon inflation. By rapid pacing, the central aortic pressure approaches zero and the force pushing the balloon and stent is reduced. In the pediatric population, it is believed that this is not necessary in every patient. Second, we routinely deployed the $\mathrm{CP}$ stent using the BIB technique. With $\mathrm{BIB}$, when the inner balloon is inflated, it fixes the stent to the aortic wall, so that the stent is easily completely opened after exact positioning. This is a controversial issue especially for pediatric cardiology operators. We believe that due to the two-step technique, we did not encounter any stent maldeployment or stent embolization in our group.

Patients in this group had some different characteristics than previous studies. One of them was a 55-year-old male who was admitted for pulmonary edema. After heart failure treatment, left ventricular ejection fraction increased to $40 \%$ and CoA was discovered in the work-up of the etiology of his new onset heart failure. The second patient was newly diagnosed with hypertension resistant to four drugs. A totally occluded CoA was detected, and the case was performed as a live teaching case in our National Cardiology Congress. There are several case reports of stent implantation in completely occluded aortic coarctation [10, 11]. After crossing the lesion with a hydrophilic guide wire and then by the catheter, we inflated balloons sequentially starting with a 4-mm and then completing with 10- to 14-mm diameter balloons by gradually increasing the pressure. We chose the covered stent because of the occurrence of dissection, and to prevent subsequent aortic rupture and aneurysm formation in the early and late follow-up periods. This is the third case in the literature in which completely occluded CoA in an adult was successfully treated with covered stent implantation [11].

The third difference in the present study from previous studies is the status of left ventricular function. Two of the 11 patients had symptomatic heart failure before treatment. Left ventricular ejection fraction (LVEF) returned to normal in both patients at 1 month follow-up.

We used a covered CP stent using a BIB balloon in the majority of cases. There was no aneurysm formation or stent fracture on follow-up CT imaging. We routinely performed CT angiography at 6 months to detect aneurysms and stent fracture [15-17].

Percutaneous angioplasty, stenting, and surgical therapies have similar early and late success and complication rates. However, re-intervention rates are higher in PTA and stenting than surgery [2-10]. Treatment should be performed shortly after establishment of the diagnosis to avoid possible late complications such as congestive heart fail- ure, death, and hypertension-related events [14-19]. Half of the patients with hypertension can discontinue, or reduce the dose of antihypertensive drugs after successful surgical or transcatheter treatment of CoA. The remainder need medication despite successful dilation of COA [18].

Indications for stenting in CoA include unfavorable anatomy for balloon angioplasty such as tubular coarctation, hypoplasia of the aortic isthmus, long aortic segment stenosis [14-20], unsuccessful opening by balloon angioplasty, restenosis following angioplasty, and dissection after angioplasty. However, the majority of adult cases are commonly treated by stenting as a first line therapy [14-20]. Procedural success was defined as a decrease in the pressure gradient between the proximal and distal aorta to below $10 \mathrm{~mm} \mathrm{Hg}$ [11-20]. Aortic rupture, aortic dissection, aneurysm formation, and death are major complications which may occur during endovascular intervention.

Stents have advantages over balloon angioplasty in lowering the residual pressure gradient, and have lower rates of restenosis and direct aortic wall damage [8]. Suarez de Lezo et al. [8] also reported a 10-15\% higher risk of aneurysm development in BAP alone compared to stenting. Although the overall anatomical and hemodynamic results of stent implantation are satisfactory, CoA stenting is not without risk. Aortic rupture, stent fracture, embolization or displacements of stent are infrequent complications of stent implantation [14-21].

Most cases of isolated native or recoarctation are suitable for stent implantation in adult patients. However, complex cases such as those with additional cardiac abnormalities (significant valvular regurgitation), large aneurysms (maximum CP stent diameter $=24 \mathrm{~mm}$ ), or femoral arterial problems related to previous CoA interventions are better managed by surgery [15].

The 2008 American College of Cardiology/American Heart Association (ACC/AHA) guidelines for adults with congenital heart disease (ACHD) recommend intervention for coarctation in the following circumstances [15]: peakto-peak coarctation gradient greater than or equal to $20 \mathrm{~mm} \mathrm{Hg}$, or peak-to-peak coarctation gradient less than $20 \mathrm{~mm} \mathrm{Hg}$ in the presence of anatomic imaging evidence of significant coarctation with radiologic evidence of significant collateral flow (class IC indication). The peak-topeak gradient is a measurement derived from catheterization data in which the peak pressure beyond the coarctation is subtracted from the peak pressure proximal to the coarctation, and is usually somewhat lower than the peak systolic gradient obtained by echocardiography. The European Society of Cardiology 2010 guidelines for management of adult congenital heart disease recommended intervention in all patients with a non-invasive pressure difference $>20 \mathrm{~mm} \mathrm{Hg}$ between the upper and lower limbs, and upper limb hypertension (> 140/90 mm Hg in adults), pathological blood pressure response during exercise, or significant left ventricular hypertrophy, regardless of symptoms (class IC indication) [21]. 
Surgical treatment of coarctation is possible through several techniques: resection with end-to-end anastomosis, subclavian flap aortoplasty in infants with long-segment coarctation, a bypass graft across the area of coarctation when the distance to be bridged is too long for an end-to-end repair or prosthetic patch aortoplasty [21]. Problems with these techniques include a significant incidence of aneurysm formation with Dacron patch aortoplasty, and an unacceptably high recoarctation rate with subclavian flap aortoplasty. Paraplegia due to spinal cord ischemia and mesenteric arteritis with bowel infarction are rare complications [21].

\section{Conclusions}

Endovascular stenting for native $\mathrm{COA}$ in adults appears to be an acceptable treatment. It is associated with excellent hypertension improvement and left ventricular functional recovery. However, serious complications may occur and regular follow-up to assess long-term results of stent implantation is warranted.

\section{Acknowledgments}

This study was presented as a poster at the 2010 SCAI Global Interventional Summit, Istanbul, Turkey.

\section{References}

1. Campbell M. Natural history of coarctation of the aorta. Br Heart J 1970; 32: 633-640.

2. Carr JA. The results of catheter-based therapy compared with surgical repair of adult aortic coarctation. J Am Coll Cardiol 2006; 47: 1101-1107.

3. Walhout RJ, Suttorp MJ, Mackaij GJ, et al. Long-term outcome after balloon angioplasty of coarctation of the aorta in adolescents and adults: Is aneurysm formation an issue? Catheter Cardiovasc Interv 2009; 73: 549-556.

4. Kusa J, Szkutnik M, Białkowski J. Percutaneous reconstruction of the continuity of a functionally interrupted aortic arch using a stent. Cardiol J 2008; 15: 80-84.

5. Akdemir R, Özhan H, Erbilen E, et al. Isolated interrupted aortic arch: a case report and review of the literature. Int J Cardiovasc Imaging 2004; 20: 389-392.

6. Vriend JWJ, Lam J, Mulder BJM. Complete aortic arch obstruction: interruption or aortic coarctation? Int J Cardiovasc Imaging 2004; 20: 393-396.

7. Shennib H, Rodriguez-Lopez J, Ramaiah V, et al. Endovascular management of adult coarctation and its complications: intermediate results in a cohort of 22 patients. Eur J Cardiothorac Surg 2010; 37: 322-327.

8. Suárez de Lezo J, Pan M, Romero $M$, et al. Percutaneous interventions on severe coarctation of the aorta: a 21-year experience. Pediatr Cardiol 2005; 26: 176-189.

9. Fawzy ME, Awad M, Hassan W, et al. Long-term outcome (up to 15 years) of balloon angioplasty of discrete native coarctation of the aorta in adolescents and adults. J Am Coll Cardiol 2004; 43: 1062-1067.

10. Musso TM, Slack MC, Nowlen TT. Balloon angioplasty with stenting to correct a functionally interrupted aorta: a case report with threeyear follow-up. Catheter Cardiovasc Interv 2008; 72: 87-92.
11. Akdemir R, Agac MT, Acar Z. Aortic coarctation: angioplasty and stenting of a total occlusion. Acta Cardiol 2010; 65: 467-470.

12. Baykan A, Karagöz T, Çeliker A. Endovascular stent implantation for coarctation of the aorta in children and young adults: intermediate follow-up results from Turkey. Turk J Pediatr 2009; 51: 116-119.

13. Yazıcı HU, Göktekin O, Ulus T, et al. Our initial experience with stent implantation for aortic coarctation in adults. Turk Kardiyol Dern Ars 2011; 39: 214-218.

14. Erdem A, Akdeniz C, Sarıtaș T, et al. Cheatham-Platinum stent for native and recurrent aortic coarctation in children and adults: immediate and early follow-up results. Anadolu Kardiyol Derg 2011; 11: 441-449.

15. Warnes CA, Williams RG, Bashore TM, et al. ACC/AHA 2008 Guidelines for the Management of Adults with Congenital Heart Disease: a report of the American College of Cardiology/American Heart Association Task Force on Practice Guidelines (writing committee to develop guidelines on the manage-ment of adults with congenital heart disease). Circulation 2008; 118: e714-e833.

16. Chessa M, Carrozza M, Butera G, et al. Results and mid-long-term follow-up of stent implantation for native and recurrent coarctation of the aorta. Eur Heart J 2005; 26: 2728-2732.

17. Koerselman J, de Vries H, Jaarsma W, et al. Balloon angioplasty of coarctation of the aorta: a safe alternative for surgery in adults: immediate and mid-term results. Catheter Cardiovasc Interv 2000; 50: 28-33.

18. Białkowski J, Szkutnik M, Głowacki J, Fiszer R. Coarctation of the aorta - clinical picture and terapeutical options. Post Kardiol Interw 2010; 6: 167-172.

19. Chessa M, Carrozza M, Butera G, et al. Results and mid-long-term follow-up of stent implantation for native and recurrent coarctation of the aorta. Eur Heart J 2005; 26: 2728-2732.

20. Holzer R, Qureshi S, Ghasemi A, et al. Stenting of aortic coarctation: acute, intermediate, and long-term results of aprospective multiinstitutional registry Congenital Cardiovascular Interventional Study Consortium (CCISC). Catheter Cardiovasc Interv 2010; 76: 553-563.

21. Baumgartner H, Bonhoeffer P, De Groot NM, et al. Task Force on the Management of Grown-up Congenital Heart Disease of the European Society of Cardiology (ESC). Guidelines for the management of grown-up congenital heart disease. The Task Force on the Management of Grown-up Congenital Heart Disease of the European Society of Cardiology (ESC) endorsed by the European Pediatric Cardiology (AEPC). Eur Heart J 2010; 31: 2915-2957. 